Nigerian Journal of Physiological Sciences 22 (1-2): 27-30 @Physiological Society of Nigeria, 2007

Available online/abstracted at http://www.biolineinternational.org.br/njps; www.ajol.info/journals.njps; www.cas.org

\title{
THE CONCENTRATIONS OF METHAEMOGLOBIN, CARBOXYHAEMOGLOBIN AND SOME HAEMATOLOGICAL PARAMETERS IN TOBACCO SNUFF ADDICTS IN IGBO OF NIGERIA
}

\author{
S. O. UREME' ${ }^{1}$, I. D. IBEAGHA ${ }^{2}$, I. G. MADUKA ${ }^{3}$, O. G. IBEAGBULAM ${ }^{4}$ \\ 1Department of Medical Laboratory Science, College of Medicine, University of Nigeria, Enugu \\ Campus, Enugu, Nigeria. \\ 2 School of Medical Laboratory Science, University of Nigeria Teaching Hospital Enugu, .Nigeria \\ 3Department of Chemical Pathology, University of Nigeria Teaching Hospital Enugu, Nigeria \\ 4 Department of Haematology and Immunology, College of Medicine, University of Nigeria Teaching \\ Hospital Enugu, Enugu, Nigeria.
}

\begin{abstract}
Summary: Methaemoglobin, carboxyhaemoglobin concentrations and some haematological parameters were studied in fifty tobacco snuff addicts (40 males and 10 females) in some villages of Anambra State, Nigeria. The aim was to investigate possible adverse effects of tobacco snuff in addicts in Igbos of Anambra State. Fifty apparently healthy persons (25 males and 25 females) who do not inhale snuff were used as controls. The age range of tests and control subjects was $25-65$ years. The results showed no statistically significant difference when the tests group was compared with the control group. A comparison of the results on the basis of sex, age and period of exposure, showed no significant differences. Blood picture in test and control groups was normocytic and normochromic. The results suggest that tobacco snuff may not have any adverse effect on haemoglobin metabolism and erythropoiesis.
\end{abstract}

Key Words: Methaemoglobin, carboxyhaemoglobin, tobacco snuff and haematological parameters.

\section{Introduction}

Methaemoglobin (Hi) is the form of haemaglobin in which the iron of the haemoglobin has been oxidized to the ferric state. It cannot bind and therefore does not transport oxygen. The production of methaemoglobin occurs at a slow but steady rate in the red cells. This is caused mainly by the fact that while oxygen is being transported, it gains an electron from the iron and is transported in the superoxide anion form whereas the iron is in the ferric state. Upon normal deoxygenation, the electron of the superoxide is given back to the iron so that molecular oxygen is released and haemoglobin remains in the functional state. However, this is not perfect and consequently a small proportion of the superoxide molecules are released which causes formation of methaemoglobin (Brewer and Prassad 1993). It is continuously reduced almost entirely by the reduced nicotine adenine dinucleotide (NADH) diphorase system (Coleman and Colernan 1996). About 1-3\% of haemoglobin is converted into methaemoglobin on daily basis and without an effective reducing system, the erythrocycte becomes non-functional. Methaemoglobinaemia is a feature of unstable haemoglobins, congenital deficiency of NADH methaemoglobin reductase as well as exposure to oxidant drugs and chemicals (Beutler 1993).

Carboxyhaemoglobin $(\mathrm{COHb})$ is a product of chemical combination between carbon monoxide and haemoglobin. Carbon monoxide is one of the most common toxins encountered in work settings: the gas being emitted in situations where there is incomplete combustion of carboncontaining substances. The body burden due to inhalation of carbon monoxide is measured by an individual's blood carboxyhaemogblobin level (Wickramatilake 1999). It does not transport oxygen and toxicity results from generalized anoxia. Carbon monoxide poisoning leads to a decrease in amount of oxygen transported by haemoglobin. Thus not only does the amount of oxygen not released for cellular respiration, the affinity of oxygen for haemoglobin is reduced. The affinity of carbon monoxide for haemoglobin is about 200 times as that of oxygen and as a result, it is not displaced from haemoglobin except at high oxygen tension. Accidental poisoning can occur even at low levels of the gas in the atmosphere with prolonged exposure and this can lead to cell death through apoptosis (Varon et al 1999).

Haematological parameters like packed cell volume PCV haemoglobin ( $\mathrm{Hb})$ and 
reticulocytes are non-specific indicators of effective erythropoesis and erythrocyte functional viability. (Gilmer \& Koepke 1976). They are affected to different degrees in some haematological/metabolic diseases and hence have become immensely useful in diagnosis, progrnosis and monitoring of treatment (Onwukeme 1993).

Tobacco is the dried and processed leaves of the plant Nicotine Tobacum Linn which is widely cultivated in America and some West African countries. It is yellowish brown in colour with a strong odor and bitter faste. The principal content of tobacco is nicotine. It has no use in Medicine though it is of value chiefly as an insecticide (Feyerabend and Russell 1979). Tobacco snuff is in powered form with potash and sweeteners as the main additives. In Igbo communities of Nigerian where it is utilized for cultural and traditional purposes, it is either inhaled through the nose or applied orally. Some addicts also chew the dried leaves. Nicotine has been associated with addiction in regular smokers and snuffers. Cryer et al (1976) stated that in small doses, nicotine has a stimulatory effect on the autonomic nervous system which causes raised blood pressure and pulse rates.

In view of the various pharmacological actions of nicotine, additives which are constituents of tobacco snuff and the wide use in many communities of Igbo tribe and possibly other communities; it is possible that haemoglobin the principal pigment in erythrocytes may be affected particularly by peroxidation. This can cause respiratory distress, which may be aggravated in respiratory disorders. This study was designed to investigate possible adverse effects of tobacco snuff on haemoglobin, its conversion products and some haematologiccal parameters.

\section{Subjects and Methods}

The subjects were drawn from fifty-tobaccosnuff addicts (40 males, 10 females) from some Igbo communities of Anambra State of Nigeria. Addiction was defined in this study as consistent and regular inhalation of tobacco snuff for a period ranging from $5-30$ years. The controls consisted of fifty apparently healthy persons (25 males. 25 females) who do not take or have never inhaled tobacco snuff. The age range of both tests and control subjects was 25-65 years. Whole blood was collected from both test and control subjects after informed consent into EDTA specimen bottles for determination of methaemoglobin, haemoglobin concentration, reticulocyte count and blood picture. The method of Evelyn and, Malloy (1938) was used for methaemoglobin determination, while the method of Van Assendelft (1970) was adopted for carboxyhaemoglobin, Drabkin and Austin method (1932) was used for haemoglobin while the method of Bain (1995) was adopted for reticulocyte count and blood picture respectively. The mean results and standards deviation (SD) were compared using students " $t$ " test.

Table 1: Mean results of $\mathrm{Hi}, \mathrm{COHb}, \mathrm{Hb}, \mathrm{PCV}$ and retics and sex comparison in test and control groups.

\begin{tabular}{|c|c|c|c|c|c|}
\hline Subjects: & $\mathrm{Hi} \pm \mathrm{SD} \%$ & $\mathrm{COHi} \pm \mathrm{SD} \%$ & $\mathrm{Hb} \pm \mathrm{SDg} / \mathrm{dI}$ & $\mathrm{PCV} \pm \mathrm{SDL} / \mathrm{L}$ & Retics \pm SD $\%$ \\
\hline $\begin{array}{c}\text { Male } \mathrm{N}=40 \\
\text { Control }\end{array}$ & $1.5 .5 \pm 0.29$ & $0.98 \pm 0.28$ & $1.3 .5 \pm 1.30$ & $0.40 \pm 02$ & $0.60 \pm 0.20$ \\
\hline Male $n=25$ & $1.52 \pm 0.24$ & $0.96 \pm 0.28$ & $1.3 .7 \pm 1.10$ & $0.39 \pm 0.03$ & $0.72 \pm 0.26$ \\
\hline $\begin{array}{l}\text { P-value } \\
\text { Females }\end{array}$ & $\mathrm{P}>0.05$ & $\mathrm{P}>0.05$ & $\mathrm{P}>0.05$ & $\mathrm{P}>0.05$ & $\mathrm{P}>0.05$ \\
\hline $\begin{array}{c}\mathrm{N}=10 \\
\text { Controls }\end{array}$ & $1.50 \pm 0.25$ & $0.92 \pm 0.18$ & $12.10 \pm 1.10$ & $0.35 \pm 0.02$ & $0.62 \pm 0.22$ \\
\hline $\begin{array}{l}\mathrm{N}=25 \\
\mathrm{P} \text {-value }\end{array}$ & $\begin{array}{c}1.52 \pm 0.24 \\
P>0.05\end{array}$ & $\begin{array}{c}0.89 \pm 0.20 \\
P>0.05\end{array}$ & $\begin{array}{c}11.9 \pm 1.10 \\
\mathrm{P}>0.05\end{array}$ & $\begin{array}{c}0.31 \pm 1.10 \\
P>0.05\end{array}$ & $\begin{array}{c}0.72 \pm 0.26 \\
P>0.05\end{array}$ \\
\hline
\end{tabular}

\section{Results}

The mean values recorded in this study when compared with controls showed no significant differences $(\mathrm{P}>0.05)$ in all parameters measured. When compared on the basis of exposure/addiction period (5 - 20 and 21 years and above) sex and age, there were no significant differences. The blood picture of both test and control groups were all normochronic and normocytic. It also showed normal platelet morphology and number while the leucocytes appeared normal qualitatively and quantitatively in almost all test subjects. However a few cases showed leucocytosis and eosinophilia. The summary of results in test and control groups and comparisons on age and exposure are presented in Tables 1 and 2. 
Methaemoglobin and arboxyhaemoglobin levels in tobacco snuff addits

Table 2: Mean Results of Age, and Exposure Basis

\begin{tabular}{|c|c|c|c|c|c|}
\hline $\begin{array}{l}\text { Subjects: } \\
\text { Age. }\end{array}$ & $\begin{array}{c}\mathrm{Hi} \pm \mathrm{SD} \\
\%\end{array}$ & $\begin{array}{c}\mathrm{COHI} \\
\%\end{array}$ & $\begin{array}{c}\mathrm{Hb} \pm \mathrm{SDg} / \mathrm{dL} \\
\%\end{array}$ & $\begin{array}{c}\mathrm{PCV} \pm \mathrm{SD} \\
\mathrm{L} / \mathrm{L}\end{array}$ & $\begin{array}{c}\text { Retics } \pm \text { SD } \\
\%\end{array}$ \\
\hline Age (yrs.) & & & & & \\
\hline $25-40$ yr $\mathrm{N}=15$ & $1.45 \pm 0.30$ & $0.94 \pm 0.22$ & $12.6 \pm 1.0$ & $0.37 \pm 0.03$ & $0.58 \pm 0.30$ \\
\hline Control $\mathrm{N}=10$ & $1.43 \pm 0.26$ & $0.95 \pm 0.20$ & $13.6 \pm 10$ & $0.37 \pm 0.03$ & $0.58 \pm 0.30$ \\
\hline P-value & $>0.05$ & $>0.05$ & $>0.05$ & $>0.05$ & $>0.05$ \\
\hline $\begin{array}{c}41-65 y r s . \\
N=35\end{array}$ & $1.57 \pm 0.35$ & $0.98 \pm 0.25$ & $12.7 \pm 1.10$ & $0.39 \pm 0.03$ & $0.65 \pm 0.26$ \\
\hline $\mathrm{N}=30$ & $1.55 \pm 0.36$ & $0.97 \pm 0.23$ & $13.0 \pm 1.0$ & $0.40 \pm .0 .28$ & $0.67 \pm 0.28$ \\
\hline Exposure (yrs) & & & & & \\
\hline $5-20 \mathrm{~N}=13$ & $1.50 \pm 0.35$ & $0.96 \pm 0.28$ & $11.9 \pm 1.0$ & $0.39 \pm 0.29$ & $0.59 \pm 0.30$ \\
\hline $\begin{array}{c}21-30 \\
N=37\end{array}$ & $1.53 \pm 0.30$ & $0.97 \pm 0.25$ & $12.1 \pm 1.0$ & $0.39 \pm 0.02$ & $0.60 \pm 0.26$ \\
\hline Control $N=25$ & $1.51 \pm 0.30$ & $0.96 \pm 0.23$ & $12.3 \pm 1.0$ & $0.37 \pm 0.02$ & $0.58 \pm 0.26$ \\
\hline$[\mathrm{P}$-value & NS & NS & NS & NS & NS \\
\hline
\end{tabular}

\section{Discussion}

Some diseases have long been associated with habits, culture and environments (Feyisitan et al 1997) Tobacco in particular has been linked to cancer of the mouth and alimentary canal (Sanghi et al 1955) The results of methaemoglobin and carboxyhaemoglobin obtained in this study did not suggest any adverse effects on the functional integrity of haemoglobin. There is an excellent system for the reduction of methaemoglobin to haemoglobin, which involves methaemoglobin reductase and NADH. It is probable that this process was effective and unaffected in subjects studied. It is only when the system is overwhelmed that methaemoglobinaemia and oxidant stress result. In general xenobiotics have been shown to induce methaemoglobinaemia, Heinz bodies and haemolysis (Carrell et al 1975) In another study, Hullinquist et al (1997) reported that methaemoglobin is one of the markers of oxygen free radical production during haemolysis. There seems to be paucity of data with regard to methaemoglobin concentration in snuffers to facilitate comparison. The results are suggestive of no adverse effects on haemoglobin metabolism.

Nicotine, an alkaloid contained in tobacco is absorbed in the oral or nasal cavity of humans. Russell et al (1980) reported that blood of tobacco smokers and snuffers contained significant concentration of nicotine. The authors also reported significant value for carboxyhaemoglobin in smokers and nonsignificant value in snuffers. The result of carboxyhaemoglobin recorded in this study agrees with the author already cited. This may be due to the fact that carbon monoxide is a product of incomplete combustion, which is not a feature of snuffing.

Oxygen free radicals and reactive oxygen species are entities that have been linked to peroxidation of biomolecules. (Michaelson 1986). The results of this study also suggest that these highly reactive entities might not have been generated in increased amounts in the subjects studied since methaemoglobin, an oxidation product of haemoglobin was not increased in test subjects. It can also be implied that the total antioxidant status (TAS) was effective qualitatively and quantitatively. A reduction in levels of plasma vit $\mathrm{C}$ and $\mathrm{E}$ and increased activity of erythrocyte superoxide dismutase and lipoperoxides have been reported in cigarette smokers (Zhou et al, 1997). In general total antioxidant status has been reported to be low in many diseases (Lantos, 1997). The statistically insignificant difference obtained in this study was supported by effective erythropoesis as indicated by the results of haematological parameters (PCV, Hb, reticulocyte and blood picture). This was strengthened by data obtained when results were compared on basis of sex, age and addiction periods. The implication is that tobacco snuff may not adversely affect the measured parameters in addicts even with long period of addiction. However lower values of some parameters have been reported in smokers (Isagar and Hagerup 1971, Galea and Davidson 1985) The leucocytosis and eosinophilia that were observed in a few subjects blood picture may be due to underlying bacterial and parasitic infection. The study showed that snuffing is more prevalent amongst men $(80 \%)$. However 
the absence of adverse effect was the same in both sexes while the age group of 41-65 years recorded the highest prevalence $(70 \%)$. Carbon monoxide poisoning and increased carboxyhaemoglobin shave been reported to be a common feature in chronic cigarette smokers warranting the use of hyperbaric oxygen for clinical management (Weaver 1999). Although carbon monoxide poisoning is unlikely in snuff addiction considering the fact that there is no combustion, it is still necessary to determine its level in case the contents of snuff particularly the additives affect haemoglobin function. Moreover, tobacco snuffing is common among many Igbo communities in Nigeria and it does not appear as if similar study has been conducted in this area.

\section{Conclusion}

Although cancer of the mouth and alimentary canal have been reported in chronic tobacco snuffers and chewers, the results of this study do not suggest any adverse effect on oxygenation function of haemoglobin and erythropoesis. The study has not concluded that snuffing is totally wholesome. It is probable that methaemoglobinaemia and carbon monoxide poisoning which have been documented in chronic cigarette smokers, may not obtain in snuffing. It is concluded that tobacco snuffing does not affect the haematolpgical parameters studied.

\section{References}

Bain, J. B. (1995). Basic haematological techniques. In Practical Haematology, $8^{\text {th }}$ Edition. Dacie J. N. Lewis SM Eds. PP 1924 ELBS Hong Kong.

Beutter, F. (1993). The molecular biology of G6PD variants and other red cell enzyme defects. Am. Rev. Med. 43. 47.51.

Brewer, G. J., Prassed A.S. (1993). Biochemistry and Function of the crythron. In Haematology: Clinical and Laboratory Practice. Bick R.L ED. Mosby St. Louis Missouri. Pg. 198-199.

Carrell, R.W. Winterburn, C. C and Rachmilewitz, E.A (1975) Activated oxygen and haemolysis. Brit. J. Haemsatol . 30: 259-264.

Coleman M.D. and Colerman N. A (1996). Drug induced methaemoglobinaemias; treatment issues. Drug Saf. 1.4 (6) 394.405.

Cryer, P. E., Haymend, M. W., Santiago, J. V and Shsam, S. D. (1976). Norepinephrine and epinephrine release and adrenergic medication of smoking associated haemodynamic and metabolic events. $N$. Engl J. Med. 295: 573-577.

Drabkin, D. L. and Austin, J. H. (1932). Spectrophotometric Studies: Spectrometric constants for common haemoglobin derivatives in human, dog and rabbit blood. J. Biochem. 98; 719.

Evelyn, K. A. and Malloy, H. T. (1938). Microdetermination of oxyhaemoglobin, methaemoglobin and sulphaemoglobin in single sample of blood. J. Bio Chem 126:655.

Feyerabend, A. C., Russell, M. A. H. (1970). Improved gas chromatographic method and micrextraction technique for the measurement of nicotine in biologic fluids $J$. Pharmacol. 31: 37 -76.

Feyisitan A. J., Asa, S. Ebabolu, J. A. (1997). Mother management of childhood diseases in Yoruba land: The influence of cultural beliefs, Health Transition Rev. 7:221 - 234.

Galea, G. and Davidson, R. I. (1985). Haemorheological changes associated with cigarette smoking. J. Clin. Pathol. 138: 978.

Gilmer, P. K. \& Koepke, J. A. (1976). The reticulocyte: an approach to definition. AM.J. Clin Pathol. 66262.

Hullinquist, M., Hegbrant, J. Nilsson - Thoroell, C., Lindholm, T., Nilsson Linden, T. and Hullinquist - Bengisson (1997) Plasma oncentrations of Vit C. E. and/or malondialdehyde as markers of oxygen free radical production during haomolysis. Clin Nephrol. 47 (1) 37- 46.

Isager, I. I. and Hegerup, L. (1971). Relationship between cigratte smoking and high packed cell volume and haemoglobin levels. Scand J. Haematol. 8:241.

Lantos, J., Roth, E., Zopf, I., Nemes, J., Gal, I. (1997). Monittoring of plasma total antioxidant status in different diseases .Acta Chir. Hung. 36 (1-1) $188-198$.

Michaelson, M. I. (1986). Free radicals and diseases: treatment and clinical application with superoxide dismutase. In Free Radicals Aging and Degenerative Diseases. Eds. Johnson Jr. Walford R. Harman D. Miguel J. Alan R . Liss Inc. New York 263 - 291.

Onwukeme, K. E. (1993) Haematological indices of Nigerians with sickle cell anaemia. Nig. Med. Practitioner 25: 3:25-28

Russell, M. A. (1980). A new age for snuff. Lancet. 816.475.

Weaver, L. K (1999). Carbonmonoxide poisoning. Crit. Care. Clin 15(2) 297-317.

Zhou, J. and Guo, F. Qian, Z. (1997). Effects of cigarette smoking on antioxidot vitamin and activities of antioxidases. Chun-Hua-YuFang Hisueh Tsa-chih 31(2) 67-70

Received: $27 / 2 / 2006$

Accepted: 15/2/2007 